\title{
The Ideological Leading in the Construction of Campus Culture in Middle School
}

\author{
Wanxue Zeng \\ High school affiliated to Southwest University \\ Chongqing, China 400715
}

\author{
Yuanyuan Yang \\ High school affiliated to Southwest University \\ Chongqing, China 400715
}

\begin{abstract}
Middle school culture, as an important part in human civilization system, is a soul underline for spreading knowledge, innovation, cultivation and science research. Among middle school culture construction, ideology guiding is a key to education improvement and build inner ability in school education, with the implementation of basic education curriculum upgrade and all-round education. The construction benefits students directly and indirectly, and further helps them build fine judgment, personality, mortality, even behavior and habits. Taking into full consideration of principles of Ideological and Political Pedagogy, Internalization surpasses forms, contents, and externalization. The author attempts to analyze existing problems in school culture construction with personal experience in University of Windsor, working in high school afflicted of southwest university school's home and aboard, and tires to propose suggestions and resolutions to effectively enhance middle school culture construction.
\end{abstract}

Keywords-middle school's culture construction; ideology guiding; problems; solution(s)

\section{INTRODUCTION}

As a relatively independent subculture, middle school campus culture is an important part of social culture. In the construction of campus culture in middle school, thought leading is the key, it must run through the entire construction of the middle school campus culture so as to achieve the goal of constructing a better campus. The main functions of the construction of campus culture in middle school are thought leading function, management and restriction function and cultivation and stimulating function. There are internal logical relations in these three functions.

At present, the achievements of the construction of campus culture in middle school in our country reflects in four aspects mainly: the material culture construction, the spiritual culture construction, the institutional culture construction and the behavior culture construction. The construction of campus culture in middle school has made some achievements, but the achievements of spiritual culture construction are not enough. At the same time, there is a misunderstanding that the material culture is completely equivalent to the material wealth, which makes the thought leading function inadequately in the construction of campus culture based on material.
In the construction of campus culture in middle school, the expression is the carrier, the goal of the carrier is to highlight the content, the role of the content is to promote students' Internalization, internalization not only can let students feel that they are educated, it's ultimate purpose is to externalize their actions with their thoughts and to achieve the unity of knowing and doing. On the specific circumstances of the construction of middle school campus culture in our country, there are some problems in the process of "carrier-internalization-externalization", which makes thought leading function inadequately. The main reasons are the following four points:

- The infected objects of campus culture construction in middle are fuzzified.

- The public opinion environment of campus culture construction in middle school is complicated

- The content form of campus culture construction in middle school is cosmetic.

- The management and evaluation of campus culture construction in middle school is empty.

Aimed at the goal of how to implement the idea of thought leading in the middle school campus culture construction, the author combines his own experience, takes the Glenwood Public School of Windsor in Canada and the high school affiliated to Southwestern University in Chongqing in China as the examples, and puts forward some feasible strategic suggestions, which links school with students to enhance the pertinence; focus on the innovation of form and content to enhance the attractiveness; stress on thinking and leading function to heighten the actual effect.

\section{THE CONNOTATION AND THE ANALYSIS OF THE FUNCTION OF THE CAMPUS CULTURE CONSTRUCTION IN MIDDLE SCHOOL}

\section{A. The Connotation of the Campus Culture Construction in Middle School}

Campus culture in middle school is an integral part of the culture. As for the definition of culture, the British scholar Taylor first pointed out in his treatise "primitive culture" from the broad sense of racial theory that: "culture or civilization is a complex whole which includes knowledge, belief, art, morality, law, customs, as well as all the other 
abilities and habits which social members have. ${ }^{1}$ Thus, culture consists of material culture and spiritual culture, ${ }^{2}$ and values and the specific standards is the core content of the culture. ${ }^{3}$ The campus material culture promotes the influence of the campus spiritual culture, and the key to the campus spiritual culture is thought leading.

To sum up, as a relatively independent subculture, middle school campus culture is an important part of social culture. In the construction of campus culture in middle school, thought leading is the key, it must run through the entire construction of the middle school campus culture so as to achieve the goal of constructing a better campus. The construction of campus culture in middle school must make the middle school as the research center, the students as the object, the school staff as the guide, strengthen the thought leading, so that all members of the school can create and abide by the cultural norms consciously in the long-term practice, and explicit these cultural norms by all members' behaviors and spiritual features. In the construction of campus culture in middle school, thought leading is the key, it must run through the entire construction of the middle school campus culture so as to achieve the goal of constructing a better campus.

\section{B. The Function of the Campus Culture Construction in Middle School}

The main functions of the construction of campus culture in middle school are thought leading function, management and restriction function and cultivation and stimulating function. There are internal logical relations in these three functions.

1) The thought leading function: Culture is the product of the times, it develops along with the times. ${ }^{4}$ The construction of campus culture in middle schools is bound to be influenced by social culture, shows the distinctive features of the times, and embodies the times in the process of constant innovation and development. At the present stage, the construction of high school campus culture should make the strengthening of thought leading and political guidance as the basic task, the Chinese Dream and the publicity and education of socialism with Chinese characteristics as the theme, the study and implement of the spirit of the General Secretary $\mathrm{Xi}$ Jinping's series speech as the guide, the cultivating and implementing socialist core values as the main line, enhance the accuracy, fine and lean of the work. It should actively lead the young students to strengthen their patriotism, encourage the ambition of strengthening our

${ }^{1}$ (Britain) Tylor, Edward Bernatt), translated by Lian Shusheng.. Primitive Culture $[\mathrm{M}]$. Shanghai: Shanghai Literature and Art Publishing House, 1992: 13.

${ }^{2}$ The Central Committee Marx and Engels Lenin Stalin Works Compilation and Translation Bureau of the CPC. Complete Works of Marx and Engels, Vol.1 [M]. Beijing: People's Publishing House, 2012: 54.

${ }^{3}$ Luo Hongtie. Principles of Ideological and Political Education [M]. Chongqing: Southwest Normal University Press, 2009: 9. 133.

${ }^{4}$ The Central Committee Marx and Engels Lenin Stalin Works Compilation and Translation Bureau of the CPC. Complete Works of Marx and Engels, Vol.3 [M]. Beijing: People's Publishing House, 2012: 234. nation, practice serving the country, consciously adhere to the unity of patriotism, love the party, and love socialism. ${ }^{5}$

2) The management and restriction function: The management and restriction function of the middle school campus culture construction has two aspects: one, through the teaching process of school education, directly facing the object, carries on a series of scheming, objective, pertinent education for the students, thus to create a potential campus culture. Two, through system construction and creating a public opinion environment, adjust the members' thoughts.

3) The cultivation and stimulating function: Campus culture is a kind of spiritual environmental and cultural atmosphere formed by a school in the long-term historical accumulation, and it can create an effect of cultivation and stimulating.

Therefore, based on the three functions of middle school campus culture construction, the management and restriction function is the foundation, the cultivation and stimulating function is the process, the thought leading function is the goal, and the key to the campus spiritual culture is to strengthen the research of thought leading, and to maximize the realization of thought leading function in middle school campus cultural construction.

\section{ANALYSIS OF THE CURRENT SitUATION OF CAMPUS Culture Construction In MidDle SCHOOL}

\section{A. The Achievements of Campus Culture Construction in Middle School}

At present, the achievements of the construction of campus culture in middle school in our country reflects in four aspects mainly: the material culture construction, the spiritual culture construction, the institutional culture construction and the behavior culture construction.

The construction of campus culture in middle school has made some achievements, but the results are mainly reflected in material, system, behavior and other aspects. In cultural forms, taking the middle school campus culture construction as the research object, it embodies mainly in two aspects: the material culture and the spiritual culture, and the material culture is the hardware of campus culture, the spiritual culture is the core and soul of campus culture. ${ }^{6}$ So the achievements of spiritual culture construction are not enough. At the same time, there is a misunderstanding that the material culture is completely equivalent to the material wealth, which makes the thought leading function inadequate in the construction of campus culture based on material.

\footnotetext{
${ }^{5}$ Wang Shimin. On the Contemporary Function of the Chinese National Spirit [J]. Party and Government cadres Forum, the $1^{\text {st }}$ periodical, 2005 (NPC document copy of the "Ideological and Political Education", the $4^{\text {th }}$ periodical, 2005).

${ }^{6}$ Luo Hongtie. Principles of Ideological and Political Education [M]. Chongqing: Southwest Normal University Press, 2009: 9. 134.
} 


\section{B. The Problems Existing in the Construction of Campus Culture}

1) Emphasizing the "exterior" and ignoring the "interior", emphasizing the form and ignoring the content: Through on-the-spot investigation and referring to the results of relevant research, it can be found that different schools emphasis on the construction of material explicit facilities, and the construction of campus culture is rich in material civilization, but the actual effect is not good, and it can not arouse the students' spiritual resonance and the deep influence in the future.

As the carrier of spiritual culture, it should meet the following two basic requirements: first, it should bear and transmit information, and can be manipulated by the builders of campus culture. Second, it should be a kind of material form that connects the subject with the object, and they can interact with each other in this form. If a school wants to make a good use of the activity carrier, and fully realize the thought leading function in middle school campus cultural construction, it should do the following four points: one, strengthen the guidance of campus culture construction activities in middle school; Two, the activities should have clear aims; Third, rather to be old-fashioned, outdated activities, the activity forms should be rich and colorful and attractive based on the actual situation; four is the form of activity should be practical; Forth, the activities should focus on practical results. ${ }^{7}$

At present, in the construction of campus culture in middle school, there is a general tendency to emphasize the "exterior" and ignore the "interior", the phenomenon of "emphasizing the form and ignoring the content" is very prominent.

2) Emphasizing the "content" and ignoring the "internalization", the form is more important than the content: The main content of campus culture construction in middle school is the creation, organization, development and evaluation of campus cultural activities in middle school, and the purpose of the activities is to internalize the thought.

According to the subject and object research in the principals of ideological and political education, ${ }^{8}$ the objects of the construction of campus culture in middle school are students. On the basis of fully grasping that the students have the features of the main body, level quality and dynamic quality as the object of ideological and political education, achieve the goal of internalize the content of education. In order to achieve the goal, we must focus on the needs of the object, focus on exploring the rule of psychological development, and transform the ideological and moral standards in the campus culture into the individual consciousness of the objects.

\footnotetext{
${ }^{7}$ Luo Hongtie. Principles of Ideological and Political Education [M]. Chongqing: Southwest Normal University Press, 2009: 9. 138.

${ }^{8}$ Luo Hongtie. Principles of Ideological and Political Education [M]. Chongqing: Southwest Normal University Press, 2009: 9. 51-59.
}

By referring to the previous investigation and interviews, it is found that forms of the campus cultural activities in middle schools should be further expanded, and the arrangements of forms should be further optimized. It should not focus on the content but ignore the requirement of internalization. At present, public awareness and recreational and sports activities are the main part in the construction of campus culture in middle school, and the practical activities are less, which makes a big gulf between the content and the internalization of the construction of the campus culture in middle school.

3) Emphasizing the "content" and ignoring the "internalization", the form is more important than the conten: Activities of middle school campus culture construction should pay attention to their direct results and their influence to the participants. The standards of testing the effectiveness of campus cultural activities should include whether the activities members take initiative actions or not, whether the activities fully contribute to the development of students, whether they cultivate positive school ethos and campus culture. At present, the middle school campus cultural activities have numerous kinds, but few of them are attractive or demonstrative. Most of the content of the acttivities are entertaining or superficial, while few can really inspire people to think about them. The design of the content is not novel, but lacks attraction and appeal. The content is single, can not well draw it's material from life, not be close to life, thus can not be close to reality, teachers or students.

In the construction of campus culture in middle school, the expression is the carrier, the goal of the carrier is to highlight the content, the role of the content is to promote students' Internalization, internalization not only can let students feel that they are educated, it's ultimate purpose is to externalize their actions with their thoughts and to achieve the unity of knowing and doing. On the specific circumstances of the construction of middle school campus culture in our country, there are some problems in the process of "carrier-internalization- externalization", which makes thought leading function inadequately.

\section{Analysis of the Problems Existing in the Construction of Campus Culture \\ 1) The infected objects of campus culture construction in middle are fuzzified.}

First, the understanding to the subject of campus culture construction in middle school is not clear. In the process of campus culture construction, we should focus on exploring the rule of psychological development of the students, strengthening the inspection of the students' values. Based on a comprehensive understanding of the development characteristics of the students in a certain stage, fully bring teachers into playing leading role and at the same time fully mobilize students' subjective initiative. Second, lack of understanding of the functions of middle school campus culture construction, ignoring that the campus cultural construction influence teachers and the students through the 
functions such as thought leading function, management and restriction function and cultivation and stimulating function. Thirdly, part of the school leaders' ideas are behind the times, of middle school campus culture construction idea lags behind, the understanding of themselves are insufficient, their self-given positions are inaccurate, lack of in-depth research, value orientations are too utilitarian, the imitation are excessive and lost its own characteristics.

2) The public opinion environment of campus culture construction in middle school is complicated

Since the beginning of the new century, with the rapid development of information technology, new media constantly emerge, and the construction of campus culture in middle schools is facing reshaping. Compared with the traditional media, new media communication has the characteristics of multi subject, resolution of the communication level, diversity of communication means, the degasification of the communication content, the improvement of the timeliness. The situation of public opinion in the new media can be said to be the "mirror" of social reality, however, our country is in a special period, coupled with the new media technology, the characteristics of capital led and the phenomenon of "network navy" and fans economy make the situation of public opinion complicated. The influence of new media on students is very profound. The complicated public opinion environment has brought great challenges to the construction of campus culture. ${ }^{9}$ Because the power of thought leading is insufficient, the ability of campus culture construction to cope with the complex public opinion environment is insufficient.

3) The content form of campus culture construction in middle school is cosmetic

First, the campus culture has become "an empty shell", and it lacks the understanding of its historical heritage. Second, it lacks the excavation and exploration and promotion of its own cultural significance, and can not show the connotation of campus culture, which makes campus culture construction in middle school cosmetic. Thirdly, the process of the construction of campus cultural in many schools is similar, which can not reflect their own characteristics. Fourth, in the process of the construction of campus culture, many schools have ignored the research of the students' reception ability and amount acceptance. They only pay attention to the construction of the forms, but ignored the characteristics of the subject and their own schools' profound connotation, which makes campus culture construction in middle school cosmetic.

4) The management and evaluation of campus culture construction in middle school is empty

The absence of management and the lack of independent and professional campus culture construction department can easily lead to the inefficiency of campus culture construction in middle school. In some schools, even if the related management departments are established, they do not know how to manage and evaluate the construction of campus

${ }^{9}$ Luo Hongtie. Principles of Ideological and Political Education [M]. Chongqing: Southwest Normal University Press, 2009: 9. 161. culture in middle schools. Even if they find problems, they lack the ability to analyze and improve them. ${ }^{10}$

The infected objects of campus culture construction in middle are fuzzified, and they do not make multidimensional division and research to the subject and object in the construction, which weakens the function of thought leading, restricts the realization of leading thoughts in middle school campus culture construction, and also makes the thought leading function inadequate. The essence of the process of middle school campus culture construction is a process of ideological and political education. ${ }^{11}$ The middle school campus culture construction can succeed only in the premise of the leading thought. At every step of the ideological and political education, strengthen the guidance of thought leading, correct its process, form, content, practice, all of them must take thought leading as the cornerstone serve it.

\section{The Strategic Suggestions of CAMpus Culture CONSTRUCTION}

Take the campus culture construction of Glenwood Public School in Windsor, Canada and the Affiliated Middle School of Southwestern University in Chongqing, China as examples.

\section{A. Linking Schools to Real Students and Increase Pertinence}

Case One: At the end of 2015, before the biggest cold wave sweeping Chinese, the Tibetan kids in Rangtang County, Aba Prefecture in Sichuan province put on clothes donated by the students outside in Class Two in the Attached middle school of Southwestern University of Chongqing. The students defined the activity as a public welfare activity called "the warm sun in winter, the warm love in clothes". In order to send the clothes to the Tibetan children's hands smoothly, the students took efforts to contact the Public Security Bureau in Rangtang County, and finally persuaded the courier company to send the clothes in free of charge... In order to protect the students who were in hundreds miles away, the students were so warm-hearted, and they composed a song of love, which is the result of " Three Dimension Cultivation on moral education" advocated and practiced by the Attached middle school of Southwestern University.

\section{Case Two: Students interview the Colorful festival}

Every year the Attached Middle School of Southwestern University will hold colorful art festival to make the students' life more beautiful.

In the Attached Middle School of Southwestern University, the core spirit of "colorful education" is "Cultivating People", and the basic characteristic of the education strategy is "Cultivation". The colorful festival that can reflect the colorful education most has become a course

\footnotetext{
${ }^{10}$ Luo Hongtie. Principles of Ideological and Political Education [M]. Chongqing: Southwest Normal University Press, 2009: 9. 187-189.

${ }^{11}$ Luo Hongtie. Principles of Ideological and Political Education [M]. Chongqing: Southwest Normal University Press, 2009: 9. 91-98,101-106.
} 
after many years of development. In this course, there are beautiful melodies, graceful dances, creative originality, and brilliant interpretation. Students can constantly enhance their self-confidence, enrich themselves, perfect themselves in this comprehensive moral education, which builds a strong and straight "spine" for their life.

We should closely integrate with the psychological development of the students in middle school, get close to the students' "Proximal Development Zone"12. Adhere to the principle and method of "One jump, one get" in the cultural construction of school moral education. The content should be designed close to the students, and also give students space and stage to fully show themselves and improve their abilities. It should be student-centered and be popular among them.

\section{B. Pay Attention to the Innovation of Form and Content and Enhance Its Attraction}

Activity One: In Canada, there are no moral qualities course in the primary and secondary schools. Take Glenwood Public School as an example, the school has an educational theme every month, and the monthly activity will be carried out around the theme, such as Thanksgiving Month. The students in Third Grade will make twodimensional code video together with their teachers. The student will design the two-dimensional code in the middle of the photo of themselves and their mothers, and their mothers scan the two-dimensional code using a mobile phone or iPad, then it will automatically switch to the designed Web Page, and begin to play the thanksgiving video made by students. The form and content is very novel, and it is the "education revolution in Internet background". Every student is willing to participate in such activities, and in the process, they have a certain understanding of the theme of "thanksgiving", which is externalized as the specific practices, helps students form a correct outlook on life, the world outlook and values, and appreciate their parents, love their families, further extends to their love for the nature and society.

Activity Two: Canadian schools also attach importance to the education of patriotism and internationalism. For example, the school flag is hoisted in front of the school door, students should sing the National Anthem together in the morning, and they also sing the national anthem when there are important activities. Schools often invite some celebrities or veterans to introduce their experiences to students. Every year the school organizes students to visit museums, former residences of celebrities, and some historical sites, etc. There is a survey showing that each year among the visitors to the former residence of Bethune, the students account for a big proportion.

\footnotetext{
${ }^{12}$ Vygotsky's research shows that education can play a leading role in promoting the development of children, but the two levels of child development must be determined: one is the level of development that has reached; the other is the level of development that is possible for children, which is manifested as "children can not complete the task independently, but with the help of adults, in the collective activities, by imitation, they are able to complete these tasks." The distance between these two levels is the " proximal development zone".
}

\section{Highlights Thought and Values Leading and Increase Its Effectiveness}

The Attached middle school of Southwestern University created the "Three Dimension Cultivation on moral education" to care for students' good future. The "Three Dimension Cultivation on moral education" takes moral education in time as longitude, moral education in space as latitude, total moral education as axis, pointing to the good future of the students, to achieve the goal of all-round implementation of "moral education". The "Three Dimension Cultivation on moral education" stresses on thought leading and focuses on active design. "The practicing of moral education is the process of its effectiveness. The maximum of moral education can not be separated from the moral education course which takes activity as its carrier." The "Three Dimension Cultivation on moral education" puts the thought leading in the primary position and takes the form and content as the focal point, and gets close to the real students, to take the mission of cultivating students, to create an honest and quiet atmosphere of campus culture, to realize the cognitive innovation in creating novel activities, to promote recognition with rich, colorful and effective activities, to promote the practice of multidimensional quality courses. The thought leading gets throughout the whole process, at the same time every sections create conditions for thought leading function of the construction of campus culture, so as to realize the goal from the form to content, from the content to the internalization, from internalization to externalization, thus to maximize the thought leading function of the construction of campus culture.

\section{CONCLUSION}

As a relatively independent subculture, middle school campus culture is an important part of social culture. In the construction of campus culture in middle school, thought leading is the key, it must run through the entire construction of the middle school campus culture so as to achieve the goal of constructing a better campus. The construction of campus culture in middle school must make the middle school as the research center, the students as the object, the school staff as the guide, strengthen the thought leading, so that all members of the school can create and abide by the cultural norms consciously in the long-term practice, and explicit these cultural norms by all members' behaviors and spiritual features. In the construction of campus culture in middle school, thought leading is the key, it must run through the entire construction of the middle school campus culture so as to achieve the goal of constructing a better campus.

The functions of the construction of campus culture in middle school function lie in influencing the members, especially middle school students, through infection, motivation, influence and Inspiration, and internalizing the outstanding cultural temperament into common beliefs of the students and teachers as well as the individual pursuit, naturally improving themselves which is conducive to optimizing the educational philosophy, to fully carrying out the activities, to cultivating students' core competence, thus achieve the goal of moral education. The main functions of 
the construction of campus culture in middle school are thought leading function, management and restriction function and cultivation and stimulating function. There are internal logical relations in these three functions. Therefore, based on the three functions of middle school campus culture construction, the management and restriction function is the foundation, the cultivation and stimulating function is the process, the thought leading function is the goal, and the key to the campus spiritual culture is to strengthen the research of thought leading, and to maximize the realization of thought leading function in middle school campus cultural construction.

In the construction of campus culture in middle school, the expression is the carrier, the goal of the carrier is to highlight the content, the role of the content is to promote students' Internalization, internalization not only can let students feel that they are educated, it's ultimate purpose is to externalize their actions with their thoughts and to achieve the unity of knowing and doing. On the specific circumstances of the construction of middle school campus culture in our country, there are some problems in the process of "carrier -internalization- externalization", which makes thought leading function inadequately.

The infected objects of campus culture construction in middle are fuzzified, and they do not make multidimensional division and research to the subject and object in the construction, which weakens the function of thought leading, restricts the realization of leading thoughts in middle school campus culture construction, and also makes the thought leading function inadequate. The essence of the process of middle school campus culture construction is a process of ideological and political education. The middle school campus culture construction can succeed only in the premise of the leading thought. At every step of the ideological and political education, strengthen the guidance of thought leading, correct its process, form, content, practice, all of them must take thought leading as the cornerstone serve it.

A successful construction of campus culture in middle school should take thought leading as the guidance, link the school to real students, base on the real situation of schools and students, grasp the characteristics of the objects' physical and mental development, determine its accurate position, enhance the pertinence, focus on the form and content innovation, design precisely, enhance its attractiveness, not be rejected and resented by its infected subjects, willing to take participate in the relevant activities to know, to feel, to experience, and to harvest, outstand the value of thought leading and value guidance, direct precisely, enhance its effectiveness, take sunshine to the subjects' hearts, give their feet power, and its subjects are willing to abide by and follow it, and produce positive effect and driving play on others, at the same time they dare to speak positively voice, and pass positive energy to others.

\section{REFERENCES}

[1] (Britain) Tylor, Edward Bernatt), translated by Lian Shusheng.. Primitive Culture [M]. Shanghai: Shanghai Literature and Art Publishing House, 1992: 13
[2] The Central Committee Marx and Engels Lenin Stalin Works Compilation and Translation Bureau of the CPC. Complete Works of Marx and Engels, Vol.1 [M]. Beijing: People's Publishing House, 2012: 54 .

[3] Wang Shimin. Theory of Moral Education and Culture [M] Guangzhou: Sun Yat-sen University Press, 2007: 241,246,247,257,273.

[4] Luo Hongtie. Principles of Ideological and Political Education [M]. Chongqing: Southwest Normal University Press, 2009: 9.51-59,101106,133,134,138,161,187-189.

[5] The Central Committee Marx and Engels Lenin Stalin Works Compilation and Translation Bureau of the CPC. Complete Works of Marx and Engels, Vol. 3 [M]. Beijing: People's Publishing House, 2012: 234.

[6] Literature Research Center of the CPC Central Committee. Collected Works of Mao Zedong, Volume 7 [M]. Beijing: People's Publishing House, 1996: 41.

[7] Document Editing Board of the CPC Central Committee. Deng Xiaoping 's Anthology, Vol. 3 [M]. Beijing: People's Publishing House, 1993: 44.

[8] Zheng Jinzhou. Educational Culture [M]. Beijing: People's Education Press, 2000.

[9] Wang Banghu/chief editor. Campus Culture Theory [M]. Beijing: People's Education Press, 2000

[10] Sima Yunjie. Cultural Sociology [M]. Beijing: China Social Science Press, 2001.

[11] Shen Zhuanghai. Cultural Vision of Ideological and Political Education [M]. Beijing: People's Publishing House, 2005.

[12] Shen Guoquan/ chief editor. Theory on Ideological and Political Education Environment [M]. Shanghai: Fudan University Press, 2002

[13] (US) Ray · Williams. Culture and Society [M]. Beijing: Peking University Press, 1991.

[14] (Germany) Martin. Buber. Education of Character [M]. Beijing: People's Education Press, 1981.

[15] (US) Kohlberg, translated by Qu Baokui. Moral Development and Moral Education [M]. Beijing: People's Education Press, 1989.

[16] (Japany) Cunshan Jie, Qianjing Long. The Meditations on Eastern and Western Civilization [M]. Beijing: China International Broadcasting Publishing House, 2000: 224,229.

[17] (France) Helvétius, compiled and translated by the foreign philosophy history research office of Department of Philosophy of Peking University. The French Philosophy in the 18th Century[M]. Beijing: Commercial Press. 1963: 467.

[18] Yin Yungong. Blue Book of New Media: China New Media Development Report No. 3 (2012) [M]. Beijing: Social Science Literature Publishing House, 2012.

[19] "2013 The Ontario Curriculum Social Studies Grade 1 to 6 \& History and Geography Grade 7 to 8"

[20] Ken Osborne. "Educating Citizens: A Democratic Socialist Agenda for Canadian Education"

[21] Wang Shimin. On the Contemporary Function of the Chinese National Spirit [J]. Party and Government cadres Forum, the 1st periodical, 2005 (NPC document copy of the "Ideological and Political Education", the 4th periodical, 2005).

[22] Yang Qiliang. Chinese Cultural Traditions and Traditional Moral Education [J]. Qilu Journal, the 2nd periodical, 1994.

[23] Xiong Xiaolin. The Eight Misunderstandings of Culture Construction in Secondary Schools[J]. Contemporary Education Forum (Teaching Research); 2010 (09).

[24] Liu Liheng, Huang Lifei. How to Build The Campus Culture of Secondary School under the Background of New Curriculum Reform [J]. Science and Technology Guide (Late Journal), 2010 (08).

[25] Yang Aihua. Reflection and Practice of Campus Culture Construction [J]. Education Guide, 2009 (11).

[26] Wu Jinquan. Dialectical Thinking on Moral Education and Campus Culture Construction in Secondary School [J]. Contemporary Education Forum (Principal Education Research), 2008 (11). 
[27] Deng Heqiu. On Campus Culture Construction and Human's AllRound Development [J]. Law and Society, 2008 (14).

[28] Li Xin. Study on the Campus Culture Construction of Secondary Schools [D]. Liaoning Normal University, 2011.

[29] Cao Haoming. Construction of High-quality Campus Culture in Middle School under the Background of New Curriculum [D]. Suzhou University, 2010.

[30] Wang Guangdong. Study on the Construction of Spiritual Culture in Primary and Secondary Schools [D]. Shandong Normal University, 2010.

[31] Secondary School Attached to Southwest University "3D theory on Moral Education" -Care Students for a Beautiful Life [N]. Chongqing Morning News, 2016-4-25 (5).

[32] Secondary School Attached to Southwest University: the Practice of Multi-Dimensional Quality Courses to build a Variety of Educational Examples [N]. Chongqing Evening News, 2016-3-19 (8).

[33] Jiang Zemin. An Important Speech on July 16, 2002 after Visiting the Chinese Academy of Social Sciences .

[34] (Http://world.eastday.com/epublish/gb/paper138/130/class013800009 /hwz717560.htm)

[35] Notice of the Major Work of the Communist Youth League of Schools in 2016. China Youth Network February 5, 2016. (Http://xxgqt.youth.cn/tzgg/201602/t20160205_7611179.htm)

[36] National Medium and Long Term Education Reform and Development Plan (2010-2020). Ministry of Education of the People 's Republic of China. (Http://www.moe.edu.cn/publicfiles/business/htmlfiles/moe/moe_838 /201008/93704.html)

[37] To Strengthen the Thinking Guidance and To Provide Effective Service for the Overall Situation. Kwangmyong Net, April 15, 2015. (Http://news.gmw.cn/newspaper/2015-04/15/content_105953317.htm) 